\title{
The Unblocking Leadership for Effectiveness of Teachers as Knowledge Staff: A Theoretical Framework for School Management
}

\author{
Mustafa Ozmusul \\ Faculty of Education, Harran University, Turkey
}

Copyright (C) 2015 by authors, all rights reserved. Authors agree that this article remains permanently open access under the terms of the Creative Commons Attribution License 4.0 International License

\begin{abstract}
When investigating the literature, it seems that little attention has been paid to what kind of leadership is needed for improving teacher effectiveness in terms of focusing on the obstacles that teachers face. Therefore, this study aims mainly to explore the obstacles that hinder the teachers when they do best in terms of receiving autonomy, becoming innovative, continually teaching and learning, focusing on educational quality, committing to the organization; and what kind of leadership can be performed to cope with the obstacles. On the basis of the qualitative approach, this study was conducted through two focus groups with 24 prospective students and the content analysis of the open questionnaires answered by 14 teacher participants. At the end of the study, the author of this study developed a practical and thematic leadership model for unblocking the obstacles for effectiveness of teachers. Based on this process, the model suggested that unblocking leaders should make teachers innovative and autonomous, create continually teaching and learning culture, focus on educational quality, and approach to increase organizational commitment of teachers.
\end{abstract}

Keywords Unblocking Leadership, Teacher Effectiveness, School Management, Educational Obstacles

\section{Introduction}

\section{Problem Statement}

The considerable contribution of management in $21^{\text {st }}$ century should enhance the productivity of the knowledge work and the knowledge staff. In particular, the developed countries know well how to make manual work productive. But the big challenge for them is how to make knowledge workers productive. This has been a survival issue for the future prosperity for the developed countries [17].

Drucker [17] noted six factors which could make knowledge workers productive.

1. Such productivity requires asking "what is the task?". On the contrary of manual work, knowledge work does not program staff. For instance, when a teacher face a student who feel difficulty to learn or feel unmotivated, he or she puts the lesson plan or curriculum to one side and will focus on the matter. For that, in determining process of task, the management should decide properly to eliminate the tasks of knowledge workers, and the obstacles that hinder the knowledge workers as they do best.

2. The autonomy that knowledge staff has to manage themselves is needed. Such autonomy demands that they learn how to develop them, how to stay alive mentally through the whole work-life.

3. Continuing innovation should be a considerable responsibility of the knowledge staff. Most important, the innovative teachers are required that they innovate all tools that they have from the education paradigm to teaching materials at the school.

4. Continues learning and continues teaching are should be implemented.

5. Focusing primarily on the quality rather than the quantity of outcomes.

6. Knowledge staff should be seen as the asset of organization, instead of a cost. Keep in mind, such approach should contribute to increasing the commitment of the knowledge staff to organization.

There are many factors from Socio-Economic-Status (SES) of students to school policies and implementations in achieving the aims of school as an organization. Moreover, from past to present a wide-range literature has shown that a school system cannot succeed its aims without having effective teachers. Hanushek [23] also confirmed robustly this phenomenon.

The main question, also analyzed in the present paper, is "How can teachers as knowledge workers do best their work?" in the event that the Drucker's factors play a 
considerable role in achieving aims of schools. To find some concrete answers for achieving best teachers, asking this question appears to be important with the following questions: "What are the obstacles that hinder teachers when they do best in terms of receive autonomy, become innovative, continually teaching and learning, focusing on educational quality, committing to organization?" Next, in terms of leadership perspective, a more specific question can be as follows: "Coping with those obstacles, who and how can perform a leadership?"

In summary, these questions appear to be important since we cannot expect that the obstacles are unblocked spontaneously to make best teachers. At this point, conceptualizing the unblocking leadership, this study tries to contribute to the leadership studies in terms of making teachers best as the knowledge-staff.

\section{The Obstacles that Teachers Face}

According to the literature, the obstacles that teachers face at school can be given as follows: $21^{\text {st }}$ century demands that teachers can integrate information society technologies in their classrooms. This means new skills to become digitally literate [16]. One could also consider the having limited professional knowledge or teaching experiences as the other challenges. Teachers having limited professional knowledge can be accepted as a considerable challenge to start a pedagogical change at classroom level [40]. In the literature, Winston, Van Der Vleuten, and Scherpbier [70] found a strong correlation between the long-term student outcomes and the teacher experience. Namely, they demonstrated that the experienced teachers indicated more challenging, disruptive facilitation, and dialogue through collaborative group dynamics. In addition, adaptation to and implementing the education reforms [65]; inflexibility of curricula [35]; in turn, implementation of the national curriculum [41] can be viewed as the other important challenges. Teachers also challenge to connect with the joining of resources and expertise from the communities of formal and informal schooling institutions such as museums, aquariums, and so on [34].

Furthermore, teachers challenge in the managed poorly school sanitation [13]. Working in disadvantaged places, especially in the rural areas, bring some challenges for the teachers because of the policies and procedures, work-load, economic push-pull factors, teachers' personal circumstances, and role of ambiguity of principals [42]. For instance, the young teachers with insufficient educational experiences challenge with absenteeism, overcrowding, poor school infrastructure and a plethora of local languages all affect pupil progress in the rural areas [44].

It is valuable to note the challenges that derived from students. These can be emotional and behavioral disorders such as bullying, fighting, violence, fighting, truancy, drug/alcohol abuse and sexual immorality, aggressive behaviors $[15,20,32]$; educational needs of students characterized by diversity [5]; lack of motivation and value beliefs [48]; motivational orientations in young students [69]; having low basic skills, and poor computer experiences [3].

\section{Teacher Effectiveness}

A number of scholars reported that the effectiveness of teachers depended on many factors. Some of them can be summarized as follows: The quality or effectiveness of teachers depend on the individual and group incentives [68]; value-added accountability [58]; general teaching experience and specific curriculum familiarity $[48,57]$; language use [43]; teacher-students' interpersonal relationships [18]; managing classroom misbehavior [65]; support from school principal and colleagues, being enthusiastic and motivated, flexibility and creativity, feelings of self-efficacy, well-being, [33]; using excellent teaching strategies [39]; indicating respectful to students, expert on the subject, organizing good lectures, understanding students, and having good communication skills [2]; constantly pursuing the goal [72]; personal qualities and professional development [64]; focusing classroom time on student learning [46]; empathy, fairness, happiness [30]; sociability in communication, the display of friendliness, open-mindedness, tactfulness, supportiveness, respect and humor [35]; utilization of contemporary technologies and new methods of teaching [56]; being objective [9].

\section{School Principals and Teachers}

In an effective school, principals can oversee the educational programs prepared by teachers; establish a good communication with the teachers, students and parents; restore discipline and order among students at school and classroom environments; indicate a role model to all peers with his/her attitude and speeches; give importance to students' improving their academic success; use technological tools of age and provide them for the teachers and students also utilize these tools in classroom; help students in making choices and form the goals with their teachers; are fair; fulfill their responsibilities [56]. Further, through establishing trust, promoting teacher learning, and particularly seeking support from their faculties to external expertise or helping teachers for reforming education, the effective principals play a considerable role in establishing high levels of capacity [72].

In addition, many studies have focused on the effects of these efforts of school principals to improve the approaches, attitudes and skills of teachers. To illustrate, collecting the data from 1738 teachers from the Reading First schools in Michigan in the 2006-2007 school year, Berebitsky, Goddard, \& Carlisle [4] demonstrated that the role of the principal positively impacted on the teacher collaboration. Most of all, Brown and Wynn [7] revealed that school principals having an awareness of issues affecting new teachers, a proactive approach in supporting new teachers, commitment to professional growth, and being excellence for themselves, students, and their teachers (new and veteran alike) were coeffective in keeping teachers at school. Using the data derived from 919 teachers, Rice [54] also found that "more effective teachers gave greater emphasis to poor support from the principal as a reason for leaving a school while less effective teachers gave greater emphasis to poor 
student behavior". Using the national representative data from the Schools and Staffing Survey, Price [53] indicated that the principals' relationships with their teachers made an important contribution to both of their satisfaction, cohesion, and commitment. Further; Rinehart, Short, Short, and Eckley [55] determined that the principal's social attractiveness (perceived similarity to teachers) and trustworthiness (perceived willingness to suppress one's own self-interest for the benefit of the school) were associated with teacher empowerment. More important, Jacob and Lefgren [29] found that principals could identify teachers who made largest standardized achievement. Likewise, analyzing the interviews with 30 school principals from Florida school districts, Harris and Sass [25] indicated that the principals' evaluation scores of teachers could determine modestly the high and low performing teachers in terms of contribution to the student achievement.

\section{Is a Thematic Leadership Model Needed for Teacher} Effectiveness?

Today's organizations have been complex, networked, emotional, and chaotic. However, existing leadership theories and business models base on the old world's concepts such as winners and losers, power and winners and losers, power and control, fail to consider the global interactions and what is needed to lead the postmodern organizations [52]. Therefore, in today, the leadership is not monolithic, but is pluralistic which means there are many ways to capture it. In particular, atomization and binary thinking were considerable problems of the modern thinking, in turn, more holistic approaches were needed for postmodern thinking [62]. Further; Leithwood and Jantzi [37] argued that the existing educational leadership literature did not present a unitary concept. Larson [36] pointed out that the existing implementation of educational leadership did not draw attention to the conditions of practice and professional learning need for extensive approach to equity. Hunt and Dodge [27] argued that paying attention to the temporal conditions, particularly to the treatment of time have been ignored by most leadership theories. Scheerens [59] noted that the existing practice of school effectiveness research seemed importantly atheoretical. Similarly, Irurita [28] noted that many leadership theories did not succeed to describe exactly the effective leadership. Also the theories fail to how leaders obtain and predict the context [67].

In addition, Harber and Davies [24] indicated three big problems of the current leadership literature as follows: (1) the perception of the conventional schools that ignores schooling does not equal education, (2) failing to consider the real contextuality that refers to educational organizations take place in very complex contexts, (3) lack of acknowledgment of ideology that refers to the goals including the open or hidden values, and emerged from the educational policies. Three books written by the scholars who have made a considerable contribution to the relevant literature of educational leadership have the common problem to present how decisions are made or how decisions should be made [6].
Furthermore, the school leadership literature has been mostly established by the academics from the USA, the UK, and Australia [8]. It can be said that the current literature of leadership based on the Western-centered ideology, and ignored women and the disadvantaged peoples $[1,60]$.

Thus, a considerable amount of critiques of the educational leadership models have been made in the relevant literature. They mostly argued that the models focused on the general conceptual explanations, but failed to draw attention to the thematic issues. At this point, the literature has not focused explicitly on the teacher effectiveness through as a thematic issue that is removing the obstacles that hinder the teachers when they do best.

A large body of research also has analyzed leadership and teacher effectiveness. Kington et al. [33] noted that a high level of support from the school principal's leadership could be seen as a vital factor for the effectiveness of teachers. In other words, the school principal's support and focusing on development appear to be vital for establishing the learning school organization [38]. Using the data from 1,600 teachers from the elementary schools, Goddard et al. [19] found a significant direct effect of principal leadership on teacher collaboration. Also, Park [49] revealed that the leadership style of principal significantly affected the perception of teachers about the school climate supporting for innovation. Similarly, using empirical analysis of the data obtained from 967 teachers and 32 principals in Korean vocational high schools, Park and Jeong [50] determined a significant association between the principal's initiative leadership and the decrease of the teacher resistance to change, also the emotional and behavioral dimensions. In addition, Orphanos and Orr [47] indicated that the innovative leadership preparation revealed a significant indirect effect on the teacher collaboration and satisfaction. Using data from 1500 teachers from the public elementary schools in Taiwan, Chang [11] showed that distributed leadership had a positive effect on the teachers' academic optimism. Through a meta-analysis, Chin [14] exerted that transformational school leadership affected positively teacher job satisfaction and school effectiveness perceived by teachers. Selamat, Nordin, and Adnan [63] showed that there was a strong relationship between transformational leadership and organizational commitment according to the perceptions of school teachers in the Klang district. Hord [26] also noted that engaging actively in continuing education of the teachers and improving their instructional performance as the important properties of the effective principals. In this regard, Calik, Sezgin, Kavgaci, and Kilinc [10] demonstrated that the instructional leadership had a significant direct and positive impact on collective teacher efficacy.

In sum, according to the literature of educational leadership related to teacher effectiveness, it can be said that the approaches have focused mainly on the general and theoretical issues of teacher effectiveness. In particular, little attention has been paid to what kind of leadership behavior is needed to improve the teacher effectiveness on the basis of focusing on the obstacles that teachers face. Consequently; 
based on the six factors, argued by Drucker [17], that could make knowledge workers productive, this study aims mainly to explore the obstacles that hinder teachers when they do best in terms of receiving autonomy, becoming innovative, continually teaching and learning, focusing on educational quality, committing to organization; and the leadership need to cope with these obstacles.

\section{Methodology}

To further explore the phenomenon given in the problem statement, this study was designed according to the qualitative methodology. Further, the multiple qualitative methods were used to decrease the potential bias and to ensure triangulation Two focus group interviews with prospective students lasting between 60 and 90 minutes and content analysis of the open questionnaires answered by the primary and secondary education teachers were conducted. In March 2015, following procedures were carried out for the validity of the study. First, on the basis of the related literature, particularly drawing attention to the six factors argued by Drucker [17], that could make knowledge workers productive, the author of this study determined the open questions that would be asked to the prospective students by the focus group interviews and to the teachers by the open-questionnaires. Next, the questions were reviewed by three academicians in the field of education sciences in terms of content validity, terminology, and comprehensibleness. Following this, two pilot studies were conducted with 20 prospective students and three secondary school teachers to check the validity of open-questions in terms of clearness, comprehensibleness and linguistics. After all, ten open-questions were determined for asking to both groups.

Nevertheless, at the beginning of this study, the author of this study planned to conduct the semi-structured interviews with the teachers. On the other hand, because some participants feel themselves uncomfortable and unwilling with the recorder, the researcher decided to make the open-questionnaires. It is valuable to note that all the participants took place in this study on a volunteer basis. Before starting the study, the author explained them that participating in the study would be voluntarily; anyone could leave from the study whenever he or she wanted; and the answers of the participants would not be shared or declared unethically.

\section{Data Collection Tools}

The number of questions was limited because of receiving more details and motivating the participants into the study [31]. Following the process mentioned earlier, ten open-questions were used for both focus group interviews and surveys. The questions can be organized in two parts consisted of the obstacles and leadership need. These can be summarized as follows: (a) What are the obstacles that hinder teachers when they do best especially in terms of receiving autonomy, becoming innovative, continually teaching and learning, focusing on educational quality, committing to the organization; (b) and coping with those obstacles, who and how can perform a leadership?

\section{Data Analysis and Interpretation}

In this study, Charmaz [12]' Constructivist Grounded Theory (CGR) methodological approach was used. CGR entails a constructivist interaction between researcher and participants in research process [45]. In this regard, the core categories by open coding and theoretical coding were processed to analyze the important words, demands and or ideas derived from focus-groups interviews and the open-question surveys. In addition, the author of this study used the diagramming techniques to establish a leadership concept. In the perspective of constructivist theory, the author did not report only the data derived from the participants but also approached comparatively to evaluate the all the data sources and literature.

The author interviewed interactively with the volunteered focus groups and recorded the answers of the participants into the word processor computer software and transcribed the data. Also the questionnaires with the open questions were submitted to the teachers to participate voluntarily in the study. The collected questionnaires were entered to the computer and analyzed by the author in accordance to CGR.

\section{Participants}

This study was conducted with three participant groups. First group consisted of 7 literature and 5 geography bachelor senior students who participated in the teaching traineeship at the secondary schools in 2014-2015 spring term in Sanliurfa. Second group consisted of 12 primary school teaching bachelor senior students who participated in the teaching traineeship at the primary schools in 2014-2015 spring term in Sanliurfa.

Third group consisted of 14 teachers ( 9 men, 5 women) with experiences ranged from 5 years to 22 years, who worked as the primary education teachers $(n=4)$ and the secondary education teachers $(\mathrm{n}=10)$, who held bachelor degree $(n=9)$ and master degree $(n=5)$, and some worked previously as administrator $(n=4)$ in 2014-2015 year in Sanliurfa, took part in the study.

In order to ensure the credibility of the results, the study was conducted with various participant groups. Because the purpose of the study focused on the obstacles that hindered the teachers, the primary data of the study were collected from the teachers at the primary and the secondary schools through the open-question surveys. Echoing this, the author assumed that the views of the senior students who participated in the teaching traineeship at the primary schools and the secondary schools would make considerable contribution to the study, due to their external observer role at the classrooms and the schools. For that, the data collected from the senior students were the secondary data of the study.

\section{Results}




\section{Focus-group Interviews}

In the two focus-groups the interviewed senior students shared following views:

What are the obstacles that hinder teachers when they do best in terms of becoming innovative?

The interviewed senior students reported the routinised teachers, ineffective time using at school, following old teaching methods, systematic management dimensions such as culture, climate, poor resources, and salaries as the obstacles that hindered the teachers when they did best in terms of becoming innovative. These were expressed by some students in the following statements:

"Especially elder teachers and routinised teachers do not utilize the new developments. They cannot use the smart-boards at the classrooms due to the some resistances such as traditional teaching habits, attitudes, lack of time, requiring more time and in-service education needs etc. "“

"Teachers need to rest time because of the crowded classrooms, excessive work-loads, individual home matters and etc. For that there is not time to upgrade them. "

"Teachers with démodé methods see their students as puppets "

"The general vision of school, school culture and climate, insufficient technological possibilities and features, the salaries are also other obstacles. "“

"Culturally parent attitudes also can be seen as an obstacle. As the teacher want to make innovation some parents can resist to teacher."

"Socio-Economic Status (SES) of the students can be obstacle for implementing the new and different activities".

Coping with the obstacles that hinder teachers when they do best in terms of becoming innovative, who and how can perform a leadership?

The interviewed senior students reported that through rewarding, decreasing work-loads, upgrading the skills of teachers, a humanistic management approach, holding seminars with specialists, changing traditional views of parents, school principals could perform a leadership for unblocking the obstacles hindering teachers in becoming innovative. These were expressed by some students in the following statements:

"If a teacher loves the job he or she can resist to all difficulties. This is a regarded matter with them. The successive teacher should be rewarded. The school leaders should make effort to decrease teachers' work-loads, but to increase their time to upgrade them."

"School principal should be leader rather than administrator. He or she should adopt a humanistic approach instead of bureaucracy. "

"Principal can invite various specialists to the school and organize seminars with them."

"Principal also should make efforts to change the traditional views of parents through persuasive speeches."

What are the obstacles that hinder teachers when they do best in terms of continually teaching and learning?
The interviewed senior students reported the traditional cultural pattern disallowing peer learning of colleagues with equal position and statue, and bias for sufficiency of his or her own knowledge as the obstacles that hindered teachers who took part in the process of continually teaching and learning. These were expressed by some students in the following statements:

"It can be normal to teach students, but there culturally can be problems when a teacher teach to his or her colleagues with equal position and statue. "

"Usually teachers confine themselves to their own knowledge but do not need more knowledge. Also unwillingness is another resistant point."

Coping with the obstacles that hinder teachers when they do best in terms of continually teaching and learning, who and how can perform a leadership?

The interviewed senior students suggested that school principals could hold seminars as a leadership behavior for unblocking the obstacles that hindered the teachers who took part in the process of continually teaching and learning. This was expressed by one student in the following statement:

"School principals can hold seminars for continually teaching and learning culture through ensuring that teachers to teach their colleagues."

What are the obstacles that hinder teachers when they do best in terms of focusing on educational quality?

The interviewed senior students reported the unqualified school administrators, poor school resources and working conditions, low student background, early starting of school time and etc as the obstacles that hindered the teachers in focusing on educational quality. Some students expressed the following statements:

"Having unqualified school administrators, insufficient physical infrastructure and features, ethical understanding of teachers, composed students with inadequate facilities and etc."

"Especially, the teachers teaching at the multi-grade classes cope with many difficulties such as working as a maid. "

Also a few senior students who participated in the teaching traineeship at the primary schools reported that their observed school consisted of many students with low SES who needed the basic necessities such as nourishment and hygiene, and also these matters hindered considerably the quality of education. Further, they noted that very early start of lessons and as a result of this fact, many students getting asleep as started the lessons in the morning hindered to focus on the quality.

Coping with the obstacles that hinder teachers when they do best in terms of focusing on educational quality, who and how can perform a leadership?

The interviewed senior students reported that finding and improving sources and facilities, school administration could perform a leadership for the obstacles that hindered the 
teachers in focusing on educational quality. These were expressed by some students in the following statements:

"Searching sources and donations"

"School can hold reading hours, establish and improve library and its facilities "

What are the obstacles that hinder teachers when they do best in terms of committing to the organization?

The interviewed senior students reported the unavailable central educational policies and implementations that were determined out of initiative of school administrations as the obstacles that hindered teachers when they did best in terms of committing to the organization. Some students expressed in the following statements:

"Insufficient salary, the reasons preferring the job such as parent pressure"

"Especially, new teachers start with idealism but get exhausted after years and feel strange from the job."

"Lack of a fully developed education system, frequently changed the educational policy and implementations, occupational discrimination, discrediting the teaching profession, not supporting the teachers adequately in difficult situations, temporarily employed teacher policy, the appointment policy of the teachers from various sources apart from faculty of education."

Coping with the obstacles that hinder teachers when they do best in terms of committing to the organization, who and how can perform a leadership?

The interviewed senior students reported that holding activities that enhanced the motivation of teachers, and through progressive management processes, school administrators could perform leadership for unblocking the obstacles that hindered teachers in committing to the school. Some students expressed in the following statements:

"School administrators can hold social activities, parties, sport activities, appraisal implementations, selection of the teacher of the month and etc."

"School principals must exert pressure, but create a positive climate and shared leadership at the school. "

What are the obstacles that hinder teachers when they do best in terms of receiving autonomy?

The senior teachers considered that making autonomous teachers was a structural matter. In particular, they noted that the management of education and making decisions regarding education and the teachers were conducted centrally by MEB (Ministry of National Education) authorities. Also, the bureaucratic hierarchy, committing to the rules and the regulations were the other obstacles that hindered the autonomy of the teachers. More important, the inflexible curriculum, the lesson books that were determined by the ministry of education, hindered the teachers to be autonomous on the decisions regarding their lessons. Further, they expressed that personality traits of teacher was another challenge.
Coping with the obstacles that hinder teachers when they do best in terms of receiving autonomy, who and how can perform a leadership?

The interviewed senior students reported that the ministry authorities should make effort due to the central management policies for unblocking the obstacles that hindered teachers in receiving autonomy.

\section{The Answers of the Open Questionnaires}

As the third participant group of this study, 14 primary and secondary school teachers, who worked at the public schools in 2014-2015 year in Sanliurfa, answered the open questionnaires. As shown in Table 1, the participated teachers reported seven obstacle categories entitled curriculum, student, school, teacher, school management, exam system, and education policy that hindered the teachers when they did best in terms of becoming innovation.

Answering the open questionnaires, the students reported seven obstacle categories entitled curriculum, student, school, teacher, school management, exam system, and education policy that hindered the teachers when they did best in terms of becoming innovative.

Of the participated teachers, one half reported that teachers had insufficient motivation, satisfaction and skills to become innovative for doing best. Some teachers expressed in the following statements: "Teachers having insufficient occupational skills "; "Teachers generally use classic teaching methods"; "There is only tiredness for hard worker teachers". In turn, this challenge seems to depend mostly on teachers. Among the important obstacles, around 30\% of the teachers reported low student background and motivation, and centrally decided curriculum; and less than $22 \%$ reported inadequate school infrastructure and crowded classrooms, bad school management, exam-focused education system, and education policy without systematic needs. In brief, the obstacles that hindered teachers when they do best in terms of becoming innovative seem as multidimensional problematic.

As pointed out in the Table 1.1, the teachers reported various leadership behaviors that were in four categories entitled climate, programme, seminars, and reward for coping with the obstacles of becoming innovative. Of the participated teachers, nearly half percent reported that administrators should endeavor to establish a supportive climate. These were expressed by some teachers in the following statements: "school administrators must provide comfortable working climate for teachers"; "administrators must be open and supportive of new ideas"; "administrators should enable teachers to feel more valuable". In this regard, it seems that establishing a supportive climate by administrators' initiatives has been a vital issue for a leadership need in making teachers innovative at school. In addition, less than $25 \%$ of the teachers suggested that the administrators could hold seminars for ensuring professional development, use appraisal mechanisms, and set up available school programmes. 
Table 1. The reports of the teachers on the obstacles that hinder teachers when they do best in terms of becoming innovative

\begin{tabular}{|c|c|c|c|c|}
\hline Categories & Definition & $\mathrm{n}$ & $\%$ & Example obstacles \\
\hline Teacher & $\begin{array}{l}\text { Teacher motivation, } \\
\text { satisfaction and skills }\end{array}$ & 7 & 50 & $\begin{array}{l}\text { 1- Teachers having insufficient } \\
\text { occupational skills } \\
\text { 2- Teachers generally use classic } \\
\text { teaching methods } \\
\text { 3- There is only tiredness for hard worker } \\
\text { teachers }\end{array}$ \\
\hline Student & $\begin{array}{l}\text { Student background and } \\
\text { motivation }\end{array}$ & 5 & 38 & $\begin{array}{ll}\text { 1- } & \text { Students having poor background } \\
\text { 2- } & \text { Unwilling students to learn }\end{array}$ \\
\hline Curriculum & $\begin{array}{l}\text { Centrally decided } \\
\text { curriculum is an obstacle }\end{array}$ & 4 & 29 & $\begin{array}{l}\text { 1- } \begin{array}{l}\text { Teachers are forced to complete the } \\
\text { curriculum. Consequently shortage of } \\
\text { time occurs an obstacle. } \\
\text { 2- Disharmony between curriculum and } \\
\text { course schedules. }\end{array} \\
\end{array}$ \\
\hline School & $\begin{array}{l}\text { School infrastructure and } \\
\text { crowded classrooms. }\end{array}$ & 3 & 21 & $\begin{array}{ll}\text { 1- } & \text { Crowded classrooms } \\
\text { 2- } & \text { Double-shift schooling } \\
\text { 3- } & \text { Physical infrastructure of schools } \\
& \text { designed only teaching }\end{array}$ \\
\hline School management & $\begin{array}{l}\text { School management is } \\
\text { inadequate }\end{array}$ & 3 & 21 & $\begin{array}{l}\text { 1- School are not managed according to } \\
\text { the modern society understanding. } \\
\text { 2- School administrators are so much } \\
\text { prescriptive. }\end{array}$ \\
\hline Exam system & $\begin{array}{l}\text { Education is based on exam } \\
\text { focused system }\end{array}$ & 2 & 14 & $\begin{array}{l}\text { 1- It is required no changing the place of } \\
\text { the lesson subjects according to the } \\
\text { exam system } \\
\text { 2- Students depend on the exam-focused } \\
\text { education system }\end{array}$ \\
\hline Education policy & $\begin{array}{l}\text { Education policy is not } \\
\text { exactly made on the } \\
\text { systematic needs }\end{array}$ & 2 & 14 & $\begin{array}{l}\text { 1- The changes in the education system } \\
\text { are made through populist approaches } \\
\text { and the related changes are not shared } \\
\text { with the stakeholders in the education. } \\
\text { 2- In our country teachers keep away } \\
\text { from the studies that contribute to their } \\
\text { development because of the } \\
\text { characteristics of education system. }\end{array}$ \\
\hline
\end{tabular}

Table 1.1. The reports of the teachers on who and how can perform a leadership on coping with the obstacles of becoming innovative

\begin{tabular}{|c|c|c|c|c|}
\hline Categories & Definition & $\mathrm{n}$ & $\%$ & Example leadership behaviors \\
\hline Climate & $\begin{array}{l}\text { A supportive climate is } \\
\text { needed }\end{array}$ & 6 & 43 & $\begin{array}{l}\text { 1- School administrators must provide } \\
\text { comfortable working climate for teachers. } \\
\text { 2- Administrators must be open and supportive } \\
\text { of new ideas. } \\
\text { 3- Administrators should enable teachers to feel } \\
\text { more valuable. }\end{array}$ \\
\hline Seminars & $\begin{array}{l}\text { Seminars for ensuring } \\
\text { professional development } \\
\text { are needed }\end{array}$ & 3 & 21 & $\begin{array}{l}\text { 1- The problems which can be solved in the } \\
\text { schools depend on the peoples own initiatives } \\
\text { and motivation. Participating in professional } \\
\text { development programmes should be provided. } \\
\text { 2- In this issue, specialists or qualified people } \\
\text { should be utilized. }\end{array}$ \\
\hline Reward & $\begin{array}{l}\text { Appraisal mechanisms are } \\
\text { needed }\end{array}$ & 3 & 21 & $\begin{array}{l}\text { 1- Innovative teachers among the others should } \\
\text { be determined and supported with appreciation, } \\
\text { thanking and incentives. }\end{array}$ \\
\hline Programme & $\begin{array}{l}\text { School programmes are } \\
\text { needed }\end{array}$ & 2 & 14 & $\begin{array}{l}\text { 1- School administrator can make school } \\
\text { programmes in accordance to the school } \\
\text { environment }\end{array}$ \\
\hline
\end{tabular}


764 The Unblocking Leadership for Effectiveness of Teachers as Knowledge Staff: A Theoretical Framework for School Management

Table 2. The reports of the teachers on the obstacles that hinder teachers when they do best in terms of continually teaching and learning

\begin{tabular}{lllll}
\hline Categories & Definition & $\mathrm{n}$ & $\%$ & Example obstacles \\
\hline Perspective & $\begin{array}{l}\text { Narrow point of view } \\
\text { towards continually } \\
\text { teaching and learning }\end{array}$ & 6 & 43 & $\begin{array}{l}\text { 1- As teachers we do not seem hungry to learn } \\
\text { 2- There has been insufficient sensitivity to this } \\
\text { issue }\end{array}$ \\
\hline Curriculum & $\begin{array}{l}\text { The curriculum was } \\
\text { designed constrictedly }\end{array}$ & 4 & 29 & $\begin{array}{l}\text { 1- The curriculum designed by others as a } \\
\text { machine are submitted to teachers and students. } \\
\text { 2- Teachers are forced necessarily to finish the } \\
\text { curriculum }\end{array}$ \\
\hline Work conditions & $\begin{array}{l}\text { Structure and possibilities } \\
\text { of school }\end{array}$ & 2 & 14 & $\begin{array}{l}\text { 1- Teachers and students who are at the } \\
\text { crowded and suburb schools cannot motivate } \\
\text { themselves to education. }\end{array}$
\end{tabular}

Table 2.1. The reports of the teachers on who and how can perform a leadership on coping with the obstacles of continually teaching and learning

\begin{tabular}{lllll}
\hline Categories & Definition & $\mathrm{n}$ & $\%$ & Example leadership behaviors \\
\hline Motivation & 6 & 43 & $1-\begin{array}{l}\text { Administrators should serve } \\
\text { themselves to raise motivation of } \\
\text { teachers. } \\
\text { Administrators should treat teachers } \\
\text { equally and support their new ideas. } \\
\text { The laws hangs like the Damocles' } \\
\text { sword for teachers. Teachers avoid to } \\
\text { make a different thing. They lose their } \\
\text { ability to move in a narrow mold. The } \\
\text { support of school administrators for } \\
\text { teachers in that issue can be a solution. }\end{array}$ \\
\hline Awereness & & & & $\begin{array}{l}\text { An awereness towards learning need } \\
\text { should be created. }\end{array}$
\end{tabular}

As indicated in the Table 2, teachers reported various obstacles that were in three categories entitled perspective, curriculum, and work conditions that hindered teachers when they did best in terms of continually teaching and learning. Of the participated teachers, nearly one half reported that teachers had narrow point of view towards continually teaching and learning. Some teachers expressed their views in the following statements: "As teachers we do not seem hungry to learn" and "There has been insufficient sensitivity to this issue". Thus, this challenge seems to depend mostly on teachers. In addition, less than $30 \%$ of the teachers reported the curriculum that was designed constrictedly, unavailable school structure, and facilities. In brief, teacher factor was been not solely an important obstacle, but curriculum and work conditions were as well.

As pointed out in the Table 2.1, the teachers reported the leadership behaviors that were in two categories entitled awareness and motivation for coping with the obstacles of continually teaching and learning. Of the participated teachers, nearly half percent reported that administrators should endeavor to motivate teachers. In this regard, some teachers expressed their views in the following statements:

"Administrators should serve themselves to raise motivation of teachers."; "Administrators should treat teachers equally and support their new ideas" and also "The laws hangs like the Damocles' sword for teachers. Teachers avoid making a different thing. They lose their ability to move in a narrow mold. The support of school administrators for teachers in that issue can be a solution."

In brief, it seems that administrators' initiatives that motivate and ease teachers have been the vital issues as the leadership need in making teachers innovative at school. Moreover, around $21 \%$ of the teachers reported creating awareness for learning need as a leadership approach for coping with the obstacles of continually teaching and learning.

As indicated in the Table 3, the teachers reported various obstacles that were in four categories entitled school resources, student background, cooperation, and teacher quality that hindered teachers when they did best in terms of focusing on educational quality. Of the participated teachers, nearly one half reported that the insufficient school' physical conditions, facilities, and equipments were considerable obstacles. At this point, one teacher expressed in the following statement:

"A qualitative expectation cannot be expected from a system which is not sufficient quantitatively. Prerequisites for focusing quality such as shortage of teacher, equipment, laboratory and other resources must be fulfilled. We should not focus only on exam-based education system."

Consequently, the expectations that teachers focus on educational quality by their endeavors will be meaningless, unless solving the basic physical problems of schools and improving them considerably for qualitative education.

Furthermore, less than $30 \%$ of the teachers reported that serious differences of student background, lack of cooperation among stakeholders such as students, parents, and teachers, inadequate quality of teacher training were the obstacles. To conclude, because there are many factors affecting educational quality, school policy designers and administrators should care about multi factors to cope with the obstacles in terms of focusing on educational quality. 
Table 3. The reports of the teachers on the obstacles that hinder teachers when they do best in terms of focusing on educational quality.

\begin{tabular}{lllll}
\hline Categories & Definition & $\mathrm{n}$ & $\%$ & Example Obstacles \\
\hline School resources & $\begin{array}{l}\text { School' physical } \\
\text { conditions, facilities and } \\
\text { equipments are }\end{array}$ & 6 & 43 & $\begin{array}{l}\text { 1- A qualitative expectation cannot be expected } \\
\text { from a system which is not sufficient } \\
\text { considerable factor. }\end{array}$ \\
& & & $\begin{array}{l}\text { quantitatively. Prerequisites for focusing quality } \\
\text { such as shortage of teacher, equpiment, } \\
\text { labratory and other resources must be fulfilled. } \\
\text { We should not only focus on exam-based } \\
\text { education system. }\end{array}$
\end{tabular}

\begin{tabular}{lllll}
\hline Student background & $\begin{array}{l}\text { Student background widely } \\
\text { differs }\end{array}$ & 4 & 29 & $\begin{array}{l}\text { 1- Because students' achievement level is } \\
\text { important. Quality of education can be raised if } \\
\text { the students take education equally }\end{array}$ \\
\hline Cooperation & $\begin{array}{l}\text { Cooperation among } \\
\text { students, parents and } \\
\text { teachers }\end{array}$ & 3 & 21 & $\begin{array}{l}\text { 1- In my opinion, in order to raise the quality of } \\
\text { education a considerable cooperation among the } \\
\text { students, parents and teachers is needed, and } \\
\text { visions and missions should be determined } \\
\text { explicitly. In this sense, receiving a } \\
\text { conformance can occurs through quality of } \\
\text { parents. } \\
\text { 2- Parents should support teachers and attend to } \\
\text { their children in accordance to objectives. }\end{array}$ \\
& $\begin{array}{llll}\text { Matter of teacher training } \\
\text { quality }\end{array}$ & 21 & $\begin{array}{l}\text { 1- There are serious challenges towards training } \\
\text { and employing for qualified teachers. } \\
\text { 2- Not receiving support from universities for } \\
\text { in-service education activities }\end{array}$
\end{tabular}

Table 3.1. The reports of the teachers on who and how can perform a leadership on coping with the obstacles of focusing on educational quality

\begin{tabular}{|c|c|c|c|c|}
\hline Categories & Definition & $\mathrm{n}$ & $\%$ & Example leadership behaviors \\
\hline School facilities & $\begin{array}{l}\text { Initiatives of school } \\
\text { administrators for } \\
\text { improving school facilities }\end{array}$ & 4 & 29 & $\begin{array}{l}\text { 1- School administrators should inform realted } \\
\text { authorities about the inadequecies at the schools } \\
\text { and receive support. }\end{array}$ \\
\hline Guidance & $\begin{array}{l}\text { Guidance role of school } \\
\text { administrators }\end{array}$ & 4 & 29 & $\begin{array}{l}\text { 1- Administrators should be at school and guide } \\
\text { teachers permanently } \\
\text { 2- This can become reality with the } \\
\text { administrators having sharing, flexible, } \\
\text { supportive and leading attitudes. }\end{array}$ \\
\hline Parent & $\begin{array}{l}\text { Cooperation and } \\
\text { communication with } \\
\text { parents }\end{array}$ & 3 & 21 & $\begin{array}{l}\text { 1- We can create more tolerant society through } \\
\text { educating and convincing parents on this } \\
\text { matter, and developing students behavioral and } \\
\text { humanistic values. }\end{array}$ \\
\hline
\end{tabular}

As pointed out in the Table 3.1, the teachers reported the leadership behaviors that were in three categories entitled school facilities, guidance, and parent for coping with the obstacles of focusing on educational quality. Of the participated teachers, nearly $30 \%$ reported that administrators should play guidance role effectively. According to some teachers, the administrators should indicate sharing, flexible, supportive and leading attitudes, and should be at school and guide teachers permanently. At this point, the administrators' initiatives in removing the obstacles of that teachers focus on education quality have been important. Further, cooperation and communication with parents also is needed. This was expressed by one teacher in the following statement: "Through educating and convincing parents on this matter, and developing student's behavioral and humanistic values, we can create more tolerant society".

As indicated in the Table 4, the teachers reported the obstacles that were in four categories entitled receptiveness, receptiveness, economic, work environment, and management perspective that hindered teachers when they did best in terms of committing to the organization. Of the participated teachers, 64\% reported that teachers' receptiveness needs was a considerable obstacle. At this point, some teachers expressed their views in the following statements: "The values of teaching profession in the society collapsed." and "Teachers have not outstanding position socially in the society". 
At least $50 \%$ of the teachers reported economic situation as an important obstacle. This was expressed by one of them in the following statement: "Teachers should not be deprived of opportunity in terms of financial and spiritual sense. Commitment of people who love their profession should meet their needs". In addition, less than $40 \%$ of the teachers reported the weak characteristics of work environment and bad management perspective as the other obstacles. To conclude, it can be said that there have been many considerable systematic problems caused not only from school but the education system for committing to the organization.

As pointed out in the Table 4.1, the teachers reported the leadership behaviors that were in two categories entitled approachment and school for coping with the obstacles of committing to the organization. Of the participated teachers, one half reported that administrators should have a positive and supportive approachment to teachers. This was expressed by one teacher in the following statement:
"Approaches and behaviors of school administrators can remove some obstacles. In particular, establishing mutual love and respect, frankly relations, a family atmosphere through sharing all feelings and not isolating staff should be performed by administrators".

In addition, less than $15 \%$ of the teachers reported making schools more equipped as a leadership behavior. In turn, through leadership initiatives school leaders should set up the schools with clean, hygienic, healthy environment and social and sportive activities.

On the other hand, an important part of the teachers noted that removing the obstacles of committing to the organization or occupation mostly did not depend on school. In this regard, there has been a systematic dimension that arises from centrally managed education authorities. This problematic situation also can be summarized through a statement expressed by one teacher as follows: "It should be given up that schools and their problems are a burden on teachers' shoulder."

Table 4. The reports of the teachers on the obstacles that hinder teachers when they do best in terms of committing to the organization.

\begin{tabular}{|c|c|c|c|c|}
\hline Categories & Definition & $\mathrm{n}$ & $\%$ & Example obstacles \\
\hline Receptiveness & Teachers' receptiveness needs & 9 & 64 & $\begin{array}{l}\text { 1- The value of teaching profession in the } \\
\text { society collapsed. } \\
2 \text { - teachers have not outstanding position } \\
\text { socially in the society }\end{array}$ \\
\hline Economic & $\begin{array}{l}\text { Teachers' professional and } \\
\text { financial difficulties reduce } \\
\text { their commitment to the } \\
\text { profession and school }\end{array}$ & 8 & 57 & $\begin{array}{l}\text { 1- Teachers should not be deprived of } \\
\text { opportunity in terms of financial and spiritual } \\
\text { sense. Commitment of people who love their } \\
\text { profession should meet their needs. }\end{array}$ \\
\hline $\begin{array}{l}\text { Work } \\
\text { environment }\end{array}$ & $\begin{array}{l}\text { Both physical and cultural } \\
\text { characteristics of work } \\
\text { environment }\end{array}$ & 5 & 35 & $\begin{array}{l}\text { 1- Work environment should be appropriate for } \\
\text { education and teaching } \\
\text { 2- Lack of "my work-place" understanding of } \\
\text { schools. Insufficient places which make } \\
\text { teachers is a considerable obstacle. }\end{array}$ \\
\hline $\begin{array}{l}\text { Management } \\
\text { perspective }\end{array}$ & $\begin{array}{l}\text { A perspective of management } \\
\text { is needed to pay regard to } \\
\text { teachers }\end{array}$ & 4 & 29 & $\begin{array}{l}\text { 1- Schools managed with "My" understanding } \\
2 \text { - Teachers are not participated to school } \\
\text { management exactly, and are investigated and } \\
\text { inspected permanently. }\end{array}$ \\
\hline
\end{tabular}

Table 4.1. The reports of the teachers on who and how can perform a leadership on coping with the obstacles of committing to the organization.

\begin{tabular}{|c|c|c|c|c|}
\hline Categories & Definition & $\mathrm{n}$ & $\%$ & Example leadership behaviors \\
\hline Approachment & $\begin{array}{l}\text { School administrators } \\
\text { having a positive and } \\
\text { supportive approachment to } \\
\text { teachers }\end{array}$ & 7 & 50 & $\begin{array}{l}\text { 1- approachments and behaviors of school } \\
\text { administrators can remove some obstacles. } \\
\text { 2- Mutual love and respect should be existed } \\
\text { among teachers, and between teachers and } \\
\text { school administrators. Relations should be } \\
\text { frankly, but not cumpolsory. } \\
\text { 3- Commitment can increase as the relations are } \\
\text { created through a family atmosphere, and } \\
\text { sadnesses and joys are shared. } \\
\text { 4-school administrators should not be a part of } \\
\text { problems, but strive to minimize them. They } \\
\text { should also not isolate staff. }\end{array}$ \\
\hline School & $\begin{array}{l}\text { Making schools more } \\
\text { equipped }\end{array}$ & 2 & 14 & $\begin{array}{l}\text { 1- Clean, hygienic, healthy, and equipped } \\
\text { schools should be created. Schools having } \\
\text { available environment for social and sportive } \\
\text { activities should be set up. }\end{array}$ \\
\hline
\end{tabular}


As indicated in the Table 5, the teachers reported various obstacles that were in three categories entitled central structure, administration, and physical conditions that hindered teachers when they did best in terms of receiving autonomy. Of the participated teachers, around $60 \%$ reported that strictness of school curriculums, regulations, and procedures were considerable obstacles. One of them expressed in the following statement:

"I think that the biggest imposition is procedures. There are many drudgeries such as for departing from school, participation of a person from out of school into the lesson, or employing a music or folklore teacher."

In addition, of the participated teachers, one half reported that strictiveness of understanding of school administration, excessive prescriptivism were as the other important obstacles. This was expressed by one teacher in the following statement:

"Intervention of school administration on teachers. Focusing only exam results of students, but not teaching methods of teachers"

Further, less than $30 \%$ of the teachers reported insufficient physical environment and poor school opportunities as important obstacles. This was expressed by one of them in the following statement:
"Existing of much more stressful learning environment. In sum, although making teachers autonym for doing best depend mostly on central education system authorities, school administration can be important.

As pointed out in the Table 5.1, the teachers reported the leadership behaviors that were in two categories entitled initiative and relations for coping with the obstacles of receiving autonomy. Of the participated teachers, around $60 \%$ reported that school administrators' initiatives were important issue for teachers. One of them expressed in the following statement: "School administrators can trust teachers, and create an opportunity for them to take initiative and feel relax. Also they should be facilitator for teachers". In addition, less than $40 \%$ of the teachers reported that establishing positive and frank relations among teachers, participative management at school were needed.

Nevertheless, a considerable part of the teachers expressed that coping with the obstacles of receiving autonomy depended mostly on the attempts by ministerial level. In this regard, the teachers suggested making regulations in ministerial level, removing exam system in primary education, implementing an education strategy away from politics, setting up a national understanding for problem solving and etc.

Table 5. The reports of the teachers on the obstacles that hinder teachers when they do best in terms of receiving autonomy.

\begin{tabular}{|c|c|c|c|c|}
\hline Categories & Definition & $\mathrm{n}$ & $\%$ & Example obstacles \\
\hline Central structure & $\begin{array}{l}\text { Strictness of school } \\
\text { curriculums, regulations } \\
\text { and procedures. }\end{array}$ & 8 & 57 & $\begin{array}{l}\text { 1- Yearly plans and lesson books which should } \\
\text { be obeyed by all teachers. } \\
\text { 2- Unflexible curriculums } \\
\text { 3- I think that the biggest imposition is } \\
\text { procedures. There are many drudgeries such as } \\
\text { for departing from school, participation of a } \\
\text { person from out of school into the lesson, or } \\
\text { employing a music or folklore teacher. }\end{array}$ \\
\hline Administration & $\begin{array}{l}\text { Strictiveness of } \\
\text { understanding of school } \\
\text { administration, excessive } \\
\text { prescriptivism }\end{array}$ & 7 & 50 & $\begin{array}{l}\text { 1- Intervention of school administration on } \\
\text { teachers. Focusing only exam results of } \\
\text { students, but not teaching methods of teachers. } \\
2 \text { - It is not enough to know everything very } \\
\text { well to be a capable administrator. Incapable } \\
\text { persons at now are being administrators and can } \\
\text { bother teachers. } \\
\text { 3- Uncertainty of borders of teaching. It is } \\
\text { expected every job from teachers. }\end{array}$ \\
\hline Physical conditions & $\begin{array}{l}\text { Obstacles deriving from } \\
\text { physical environment and } \\
\text { opportunities of school. }\end{array}$ & 4 & 29 & $\begin{array}{l}\text { 1- Insufficient resources given by Ministry of } \\
\text { National Education. } \\
\text { 2- Lack of environment for resting and } \\
\text { preparing for lessons. } \\
\text { 3- Existing of much more stressful learning } \\
\text { environment }\end{array}$ \\
\hline
\end{tabular}


Table 5.1. The reports of the teachers on who and how can perform a leadership on coping with the obstacles of receiving autonomy

\begin{tabular}{|c|c|c|c|c|}
\hline Categories & Definition & $\mathrm{n}$ & $\%$ & Example statements \\
\hline Initiative & $\begin{array}{l}\text { School administrators' } \\
\text { initiative for teachers }\end{array}$ & 8 & 57 & $\begin{array}{l}\text { 1- School administrators can trust teachers, and } \\
\text { create an opportunity for them to take initative } \\
\text { and feel relax. } \\
2 \text { - In this issue, school administrators should do } \\
\text { their job and do not intervene teachers. } \\
\text { 3- Teacher should able to make required tasks } \\
\text { for their students and lessons unless } \\
\text { administrators and redundant permissions are } \\
\text { needed. }\end{array}$ \\
\hline Relations & $\begin{array}{l}\text { Establishing positive } \\
\text { relations among teachers at } \\
\text { school }\end{array}$ & 5 & 36 & $\begin{array}{l}\text { 1- Relations should be frank } \\
\text { 2- Solidarity among teachers is needed also } \\
\text { teachers should be participated in management } \\
\text { at school. }\end{array}$ \\
\hline
\end{tabular}

\section{Conclusion and Discussion}

Remarking a survival matter of how to make knowledge workers productive for future prosperity of the developed countries, Drucker [17] suggested six factors as the tasks, autonomy, innovation, learning and teaching, and quality that would make knowledge workers productive. Gaining inspiration from Drucker, the author of this study analyzed that how teachers as the knowledge workers could best their work.

The participated teachers reported seven obstacles as curriculum, student, school, teacher, school management, exam system and education policy that hindered teachers when they did best in terms of becoming innovative. The focus-group interviewed students also reported the parents as an additional obstacle category with a sample statement "culturally the parent attitudes also can be seen as an obstacle. As a teacher want to make innovation some parents can resist to the teacher". At this point, the teacher participants suggested various leadership approaches related to climate, programme, seminars, and reward for coping leadership for coping with the obstacles of becoming innovative. Contributing to these categories, the focus-group interviewed students reported that the school leaders should make effort to decrease teachers' work-loads, but to increase their time to upgrade them, they should be leader rather than administrator, and also they should make efforts to change the traditional views of parents through persuasive speeches.

In addition, the teacher participants reported three obstacles as the perspective, curriculum, and work conditions that hindered teachers when they did best in terms of continually teaching and learning. The focus-group interviewed students also reported learning culture as an important obstacle. A sample statement was that "It can be normal to teach students, but there culturally can be problems when a teacher teaches to his or her colleagues with equal position and statue". And then, they suggested various leadership behaviors in two categories as motivation and awareness, for coping with the obstacles of continually teaching and learning. Furthermore, the focus-group interviewed students reported that ensuring that teachers to teach their colleagues, school principals could hold seminars for continually teaching and learning culture.

Besides, the teacher participants reported four obstacles related to school resources, student background, cooperation and teacher quality that hindered teachers when they did best in terms of focusing on educational quality. The focus-group interviewed students also reported unqualified school administrators, very early starting of lessons, and education with multi-grade classes as the obstacles. And then, the teacher participants suggested various leadership approaches related to school facilities, guidance, and parent for coping with the obstacles of focusing on educational quality. Also, the focus-group interviewed students reported that schools could hold reading hours, establish, and improve library and its facilities.

The economics, receptiveness, work environment, and management perspective factors were reported as the other obstacle categories that hindered teachers when they did best in terms of committing to the organization. The focus-group interviewed students also reported the education system as an obstacle. This was expressed by one of them in the following statement: "lack of a fully developed education system, frequently changed educational policy and implementations, temporarily employed teacher policy, appointment policy of teachers from various sources apart from faculty of education". The teacher participants suggested the leadership approaches in two categories as the approachment and school for coping with the obstacles of committing to the organization. In addition, the focus-group interviewed students suggested that school administrators could hold social activities, parties, sport activities, appraisal implementations, selection of teacher of the month and etc.

Furthermore, the teacher participants reported various obstacles related to central structure, administration, and physical conditions that hindered teachers when they did best in terms of receiving autonomy. In addition, the focus-group interviewed students reported "personality traits of teacher" as another obstacle. The teacher participants suggested the leadership approaches that were in two categories as the initiative and relations, for coping with the obstacles of receiving autonomy. Further, the focus-group interviewed students reported that this challenge should be mostly solved by ministry authorities' initiatives because of the central 
management policies.

Aiming to develop a conceptual leadership framework on unblocking the obstacles that teachers face when they do best, the author of this study broadened and adapted emprically the factors argued by Drucker [17], that could make knowledge workers productive, for educational leadership, and finally suggested a theoretical model indicated in the Figure 1. The components of the model are as follows: receiving autonomy, becoming innovative, continually teaching and learning, focusing on educational quality, and committing to the organization. According to this model, it can be argued that in order to unblock the obstacles, the school leaders (a) should make teachers innovative and autonomous through preparing school programme in accordance with environment needs, creating a supportive school climate, upgrading skills of teachers, rewarding innovative teachers, decreasing work-load of teachers, changing traditional views of parents with persuasive speeches, giving initiative to teachers in a flexibility, establishing positive relations among teachers at school. (b) The school leaders should create continually teaching and learning culture through increasing motivation and awareness of teachers for learning need, also developing a peer-learning culture that ensures teachers to teach their colleagues. (c) Focusing on educational quality should be another duty of the school leaders. Further, guiding teachers permanently, setting up efficient cooperation and communication with parents. (d) Finally, the school leaders who unblock the obstacles should approach to increase the level of organizational commitment of teachers through indicating positive and supportive approachment to teachers, making schools more equipped.

Performing this leadership, school administrators appear to become unblocking leaders for coping with the obstacles. However, allowing teachers as the leaders at schools can be inevitable due to the complex nature of education. In other words, the unblocking leadership does not advocate any approaches of one-man company. It requires focusing on the obstacles that teachers face when they do their work ideally at the schools. However, this study has indicated that focusing only teachers is not sufficient to make them effectiveness. Thus, paying regard to the factors out of teachers, unblocking leaders should make efforts mostly to unblock the obstacles that teachers face, not influence only them as the classic leadership approaches advocate.

The leadership model developed in this study presents the thematic and practical view, rather than general models such as transformational, situational, contingency, or Theory $\mathrm{X} \& Y$. Further, as pointed by Southworth [62] postmodern thinking entails more holistic approach to the endeavors for seeking leadership models. For that, the unblocking model has the situational basis, because today's schools exist in a chaotic environment and the obstacles and the ways to cope them can vary from one condition to another. In turn the unblocking model does not exclude or ignore the current models, in particular developed and adapted models for education. It needs a shared leadership culture rather than advocating a one-men leadership, because unblocking the many obstacles entails considerable interaction between school administrators and teachers, and collective responsibility.

In addition, instructional leadership and transformational leadership have been debated mostly two approaches in terms of school principals' leadership role, because many earlier leadership models such as situational leadership, trait theories, and contingency theory fail particularly to focus on the behaviors of the school administrator in the educational leadership [22]. In this regard, the unblocking model needs the instructional leadership model, which is referred by Hallinger [21] as the leaders should play more active role in organizing and coordinating instruction, instructional leaders focus on creating a shared sense of purpose, fostering the continuous improvement, developing a climate of high expectations, innovative school culture, monitoring student learning outcomes, shaping the reward structure, and continuous development of staff etc. According to Hallinger [22], transformational leadership that refers to focus on making the capacity of the organization innovative, can be accepted as distributive because it entails shared vision, and commitment to school change. From this point, the unblocking leadership is transformational, because it particularly requires from the leaders to make innovative and autonomous teachers, to create a continually teaching and learning culture, and commitment of the teachers to the organization.

Moreover, there is an important gap in the literature of educational leadership related to teacher effectiveness because the literature has focused mainly on the general and theoretical issues of teacher effectiveness. Consequently, theorizing a conceptual model based on the multiple data collected from the teachers and the senior students with external observer role who participated in the teaching traineeship at the primary schools and secondary schools, this study has contributed to the current leadership approaches and to answering the question, "What kind of leadership behavior can be made to cope them or to improve teacher effectiveness". However, some future research can be suggested as follows: Especially, because the empirical data derived from this study is based on a local context, international studies towards both centralized and decentralized education systems can make an important contribution to developing the model. Also teacher effectiveness studies can be conducted through unblocking model practices. More importantly, the conceptualized model in this study is open to take contributions for development. To test the model in the practice has some difficulties, particularly in a centrally managed school system because of the factors that are outside of the school administration. Coping with these challenges, research investigating the effect of the model is required. Further, the quantative studies including empirical data through the scale development studies can contribute to understanding the model's effect. 


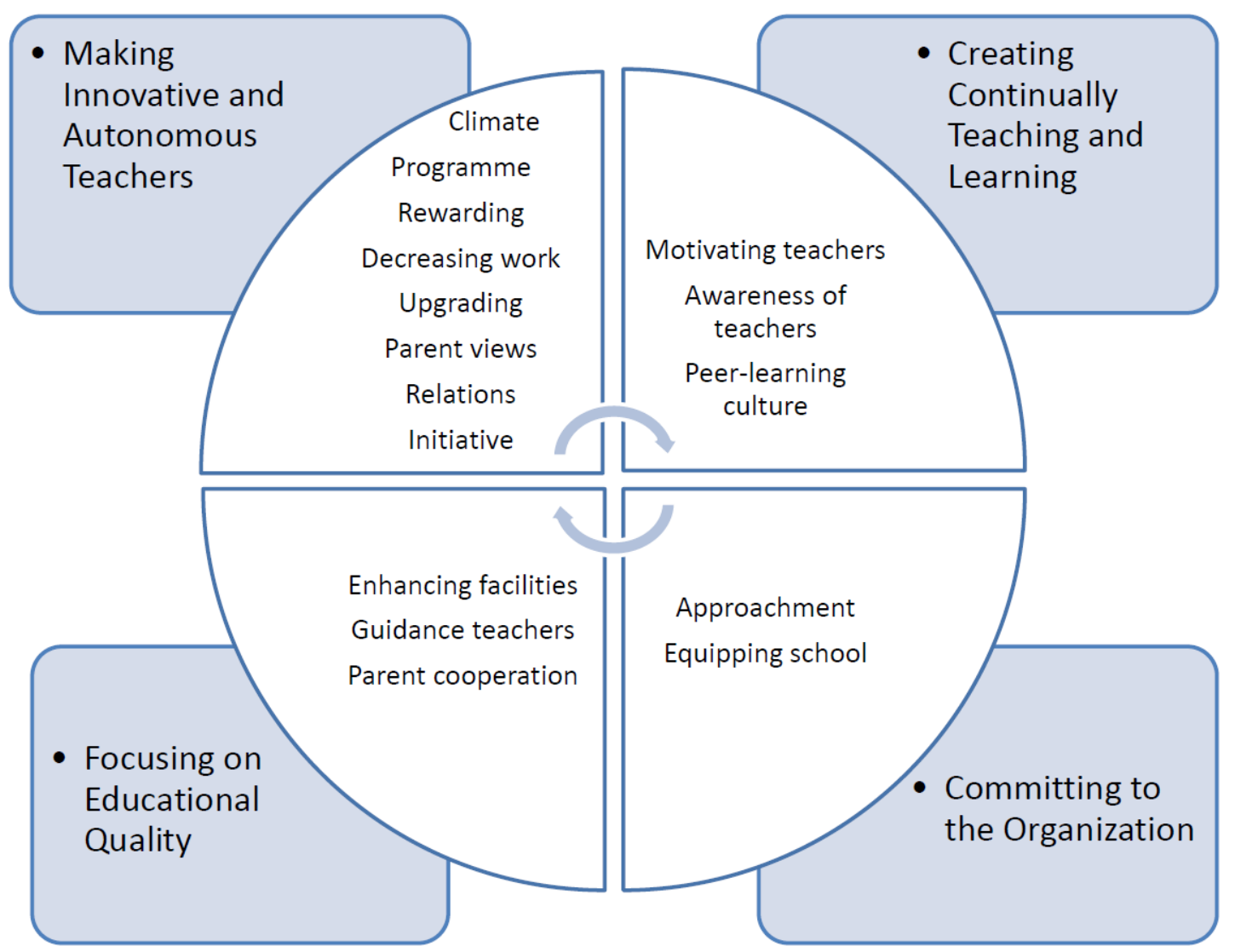

Figure 1. The unblocking leadership model: A theoretical framework for school management.(Emprically developed on the Drucker's views[17])

On the other hand, because of heavy workloads, overburdened roles, insufficient preparation and training, limited career prospects and inadequate support and rewards, there are many obstacles that school administrators face [51]. It should be also noted that unless developing educational policy and implementations through the reforms considering the school needs, the effect of leadership for unblocking the obstacles would be limited.

\section{REFERENCES}

[1] Ahnee-Benham, M. K., \& Napier, L. A. (2002). An alternative perspective of educational leadership for change: Reflections on native/indigenous ways of knowing. In Second international handbook of educational leadership and administration (pp. 133-165). Netherlands: Springer.

[2] Al-Mohaimeed, A. A., \& Khan, N. Z. (2014). Perceptions of Saudi medical students on the qualities of effective teachers A cross-sectional study. Saudi Medical Journal, 35(2), 183-188.

[3] Ates, H. (2013). Information Technology and the Learning Environment in Primary Schools. 3rd World Conference on Learning, Teaching and Educational Leadership, 93, 695-698. doi: DOI 10.1016/j.sbspro.2013.09.263

[4] Berebitsky, D., Goddard, R. D., \& Carlisle, J. F. (2014). An Examination of Teachers' Perceptions of Principal Support for Change and Teachers' Collaboration and Communication Around Literacy Instruction in Reading First Schools. Teachers College Record, 116(4).

[5] Blanco, A., \& Jorrin, V. M. (2014). To Analize The Attitudes Of Secondary School Teachers With Diversity In The Classroom. 3rd World Conference on Educational Technology Researches 2013, Wcetr 2013, 131, 497-503. doi: DOI 10.1016/j.sbspro.2014.04.155

[6] Brazer, S. D., \& Keller, L. R. (2008). A design research approach to investigating educational decision making. In A. E. Kelly, R. A. Lesh, and J. Y. Baek (Eds.), Handbook of design research methods in education: innovations in science, technology, engineering, and mathematics learning and teaching. New York: Routledge

[7] Brown, K. M., \& Wynn, S. R. (2009). Finding, Supporting, and Keeping: The Role of the Principal in Teacher Retention Issues. Leadership and Policy in Schools, 8(1), 37-63.

[8] Bush, T. (2014). School leadership in Europe: growing the field. Educational Management Administration \& Leadership, 42(4s-S), 3-4.

[9] Cakmak, M. (2009). Prospective Teachers' Thoughts on Characteristics of an "Effective Teacher". Egitim Ve Bilim-Education and Science, 34(153), 74-82.

[10] Calik, T., Sezgin, F., Kavgaci, H., \& Kilinc, A. C. (2012). Examination of Relationships between Instructional Leadership of School Principals and Self-Efficacy of Teachers and Collective Teacher Efficacy. Kuram Ve Uygulamada Egitim Bilimleri, 12(4), 2498-2504. 
[11] Chang, I. H. (2011). A Study of the Relationships between Distributed Leadership, Teacher Academic Optimism and Student Achievement in Taiwanese Elementary Schools. School Leadership \& Management, 31(5), 491-515.

[12] Charmaz, K. (2000). Grounded Theory: Objectivist and Constructivist Methods. In Norman K. Denzin \& Yvonna S. Lincoln (Eds.), Handbook of Qualitative Research, 2nd edition (pp.509-535). Thousand Oaks, Ca.: Sage publications.

[13] Chatterley, C., Javernick-Will, A., Linden, K. G., Alam, K., Bottinelli, L., \& Venkatesh, M. (2014). A qualitative comparative analysis of well-managed school sanitation in Bangladesh. Bmc Public Health, 14. doi: Artn 6 Doi 10.1186/1471-2458-14-6

[14] Chin, J. M. C. (2007). Meta-analysis of transformational school leadership effects on school outcomes in Taiwan and the USA. Asia Pacific Education Review, 8(2), 166-177.

[15] Chitiyo, M., Chitiyo, G., Chitiyo, J., Oyedele, V., Makoni, R., Fonnah, D., \& Chipangure, L. (2014). Understanding the causes and management of problem behaviour in Zimbabwean schools: teacher perceptions. International Journal of Inclusive Education, 18(11), 1091-1106. doi: Doi $10.1080 / 13603116.2013 .875068$

[16] Cortina-Perez, B., Gallardo-Vigil, M. A., Jimenez-Jimenez, M. A., \& Trujillo-Torres, J. M. (2014). Digital illiteracy: a challenge for 21 st century teachers. Cultura Y Educacion, 26(2), 231-264. doi: Doi 10.1080/11356405.2014.935108

[17] Drucker, P. F. (2007). Management challenges for the 21st century. Routledge.

[18] Fan, F. A. (2012). Teacher: students' interpersonal relationships and students' academic achievements in social studies. Teachers and Teaching, 18(4), 483-490. doi: Doi 10.1080/13540602.2012.696048

[19] Goddard, Y. L., Miller, R., Larsen, R., Goddard, R., Madsen, J., \& Schroeder, P. (2010). Connecting Principal Leadership, Teacher Collaboration, and Student Achievement (pp. 32).

[20] Grumm, M., \& Hein, S. (2013). Correlates of teachers' ways of handling bullying. School Psychology International, 34(3), 299-312. doi: Doi 10.1177/0143034312461467

[21] Hallinger, P. (2005). Instructional leadership and the school principal: a passing fancy that refuses to fade away. Leadership and Policy in Schools, 4(3), 221-239. doi:10.1080/15700760500244793

[22] Hallinger, P. (2003). Leading educational change: reflections on the practice of instructional and transformational leadership, Cambridge Journal of Education, 33(3), 329-352. doi:10.1080/0305764032000122005

[23] Hanushek, E. (2010). The difference is teacher quality. Waiting for "Superman": How we can save America's failing public schools, 81-100.

[24] Harber, C., \& Davies, L. (2003). Effective leadership for war and peace. Leadership in Education, 48-65.

[25] Harris, D. N., \& Sass, T. R. (2014). Skills, productivity and the evaluation of teacher performance. Economics of Education Review, 40, 183-204. doi: DOI 10.1016/j.econedurev.2014.0 3.002

[26] Hord, S. M. (1988). The Principal as Teacher Educator. Journal of Teacher Education, 39(3), 8-11.
[27] Hunt, J. G., \& Dodge, G. E. (2001). Leadership déjà vu all over again. The Leadership Quarterly, 11(4), 435-458.

[28] Irurita, V. F. (1994). Optimism, values, and commitment as forces in nursing leadership. Journal of Nursing Administration, 24(9), 61 .

[29] Jacob, B. A., \& Lefgren, L. (2008). Can principals identify effective teachers? Evidence on subjective performance evaluation in education. Journal of Labor Economics, 26(1), 101-136. doi: Doi 10.1086/522974

[30] Jahangiri, L., McAndrew, M., Muzaffar, A., \& Mucciolo, T. W. (2013). Characteristics of effective clinical teachers identified by dental students: a qualitative study. European Journal of Dental Education, 17(1), 10-18. doi: Doi 10.1111/Eje. 12012

[31] Johnson, A. P. (2012). A short guide to action research. "Eylem arastirmasi el kitabi" (Uzuner, Y. \& Ozten Anay, M., Translated by Eds). Ani yayincilik, Ankara.

[32] Kern, L. (2015). Addressing the Needs of Students With Social, Emotional, and Behavioral Problems: Reflections and Visions. Remedial and Special Education, 36(1), 24-27. doi: Doi 10.1177/0741932514554104

[33] Kington, A., Reed, N., \& Sammons, P. (2014). Teachers' constructs of effective classroom practice: variations across career phases. Research Papers in Education, 29(5), 534-556. doi: Doi 10.1080/02671522.2013.825309

[34] Kisiel, J. F. (2014). Clarifying the Complexities of School-Museum Interactions: Perspectives From Two Communities. Journal of Research in Science Teaching, 51(3), 342-367. doi: Doi 10.1002/Tea.21129

[35] Koutrouba, K. (2012). A profile of the effective teacher: Greek secondary education teachers' perceptions. European Journal of Teacher Education, 35(3), 359-374. doi: Doi $10.1080 / 02619768.2011 .654332$

[36] Larson, R. T. (2008). Educational leadership development for equity: Enhancing a critical theory of action. Doctoral dissertation. ProQuest.

[37] Leithwood, K., \& Jantzi, D. (2000). The effects of transformational leadership on organizational conditions and student engagement with school. Journal of Educational Administration, 38(2), 112-129.

[38] Liljenberg, M. (2015). Distributing leadership to establish developing and learning school organisations in the Swedish context. Educational Management Administration \& Leadership, 43(1), 152-170. doi: Doi $10.1177 / 1741143213513187$

[39] Liu, Y. J. (2014). Teachers' Beliefs and Effective ELF Teaching. Proceedings of the Third Northeast Asia International Symposium on Language, Literature and Translation, Vols 1 and 2, 139-144.

[40] Mac Mahon, B. (2014). Making the invisible visible: disciplinary literacy in secondary school classrooms. Irish Educational Studies, 33(1), 21-36. doi: Doi $10.1080 / 03323315.2013 .867243$

[41] Macken-Horarik, M., \& Unsworth, L. (2014). New challenges for literature study in primary school English: building teacher knowledge and know-how through systemic functional theory. Onomazein, 230-251. doi: DOI 10.7764/onomazein.alsfal.1 
[42] Mafora, P. (2013). Managing teacher retention in a rural school district in South Africa. Australian Educational Researcher, 40(2), 227-240. doi: DOI 10.1007/s13384-013-0 088-x

[43] Meacham, S., Vukelich, C., Han, M., \& Buell, M. (2013). Preschool teachers' language use during dramatic play. European Early Childhood Education Research Journal, 21(2), 250-267. doi: Doi 10.1080/1350293x.2013.789196

[44] Miller, G., \& Elman, E. (2013). Improving the quality of education: Kenya's next challenge. Geography, 98, 24-32.

[45] Mills, J., Bonner, A., \& Francis, K. (2008). The development of constructivist grounded theory. International journal of qualitative methods, 5(1), 25-35.

[46] Munoz, M. A., Scoskie, J. R., \& French, D. L. (2013). Investigating the "black box" of effective teaching: the relationship between teachers' perception and student achievement in a large urban district. Educational Assessment Evaluation and Accountability, 25(3), 205-230. doi: DOI 10.1007/s11092-013-9167-9

[47] Orphanos, S., \& Orr, M. T. (2014). Learning leadership matters: The influence of innovative school leadership preparation on teachers' experiences and outcomes. Educational Management Administration \& Leadership, 42(5), 680-700. doi: Doi 10.1177/1741143213502187

[48] Ost, B. (2014). How Do Teachers Improve? The Relative Importance of Specific and General Human Capital. American Economic Journal-Applied Economics, 6(2), 127-151. doi: Doi 10.1257/App.6.2.127

[49] Park, J. H. (2012). The effects of principal's leadership style on support for innovation: evidence from Korean vocational high school change. Asia Pacific Education Review, 13(1), 89-102. doi: DOI 10.1007/s12564-011-9182-9

[50] Park, J. H., \& Jeong, D. W. (2013). School reforms, principal leadership, and teacher resistance: evidence from Korea. Asia Pacific Journal of Education, 33(1), 34-52. doi: Doi 10.1080/02188791.2012.756392

[51] Pont, B., D. Nusche and H. Moorman. (2008). Improving School Leadership, Volume 1: Policy and Practice, OECD, Paris.

[52] Prewitt, V. (2004). Integral leadership for the 21st century. World Futures, 60(4), 327-333. doi: $10.1080 / 02604020490455450$

[53] Price, H. E. (2012). Principal-Teacher Interactions: How Affective Relationships Shape Principal and Teacher Attitudes. Educational Administration Quarterly, 48(1), 39-85. doi: Doi 10.1177/0013161x11417126

[54] Rice, S. M. (2014). Working to maximise the effectiveness of a staffing mix: what holds more and less effective teachers in a school, and what drives them away? Educational Review, 66(3), 311-329. doi: Doi 10.1080/00131911.2013.776007

[55] Rinehart, J. S., Short, P. M., Short, R. J., \& Eckley, M. (1998). Teacher empowerment and principal leadership: Understanding the influence process. Educational Administration Quarterly, 34, 630-649.

[56] Sahenk, S. S. (2010). Characteristics of the headmasters, teachers and students in an effective school. Innovation and Creativity in Education, 2(2), 4298-4304. doi: DOI

\subsection{6/j.sbspro.2010.03.682}

[57] Sass, T. R., Hannaway, J., Xu, Z. Y., Figlio, D. N., \& Feng, L. (2012). Value added of teachers in high-poverty schools and lower poverty schools. Journal of Urban Economics, 72(2-3), 104-122. doi: DOI 10.1016/j.jue.2012.04.004

[58] Sass, T. R., Semykina, A., \& Harris, D. N. (2014). Value-added models and the measurement of teacher productivity. Economics of Education Review, 38, 9-23. doi: DOI 10.1016/j.econedurev.2013.10.003

[59] Scheerens, J. (1993). Basic School Effectiveness Research: Items for a Research Agenda. School Effectiveness and School Improvement, 4(1), 17-36. doi: $10.1080 / 0924345930040102$

[60] Shockley, K. G. (2008). Africentric education leadership: theory and practice. International Journal of Education Policy \& Leadership, 3(3), 1-12.

[61] Schreier, B. M., Dicke, A. L., Gaspard, H., Hafner, I., Flunger, B., Ludtke, O., . . . Trautwein, U. (2014). The value of mathematics in the classroom: The importance of a relevanceoriented learning environment for students' value beliefs. Zeitschrift Fur Erziehungswissenschaft, 17(2), 225-255. doi: DOI 10.1007/s11618-014-0537-y

[62] Southworth, G. (2003). Learning centered leadership : the only way to go. http://research.acer.edu.au/apc_monographs/11

[63] Selamat, N., Nordin, N., \& Adnan, A. A. (2013). Rekindle Teacher's Organizational Commitment: The Effect of Transformational Leadership Behavior. 6th International Conference on University Learning and Teaching (Incult 2012), 90, 566-574. doi: DOI 10.1016/j.sbspro.2013.07.127

[64] Singh, S., Pai, D. R., Sinha, N. K., Kaur, A., Soe, H. H. K., \& Barua, A. (2013). Qualities of an effective teacher: what do medical teachers think? Bmc Medical Education, 13. doi: Artn 128 Doi 10.1186/1472-6920-13-128

[65] Sun, R. C. F. (2015). Teachers' experiences of effective strategies for managing classroom misbehavior in Hong Kong. Teaching and Teacher Education, 46, 94-103. doi: DOI 10.1016/j.tate.2014.11.005

[66] Sun, Y., \& Xie, C. S. (2014). Study on the Internal Driving Force for the Autonomous Professional Development of English Teachers in Institutions of Higher Learning. 2014 2nd International Conference on Social Science and Health (Icssh 2014), Pt 2, 56, 247-251.

[67] Teles, F. (2015). Local political leaders and context awareness: identifying perceptions of autonomy and efficacy. Space and Polity, (ahead-of-print), 1-21.

[68] Tirivayi, N., van den Brink, H. M., \& Groot, W. (2014). Group incentives for teachers and their effects on student learning: a systematic review of theory and evidence. School Effectiveness and School Improvement, 25(4), 570-601. doi: Doi 10.1080/09243453.2013.857697

[69] van der Aalsvoort, G. M., Lepola, J., Overtoom, L., \& Laitinen, S. (2015). Motivation of young students: a cross-cultural evaluation of a model for motivational orientations. Research Papers in Education, 30(1), 114-131. doi: Doi 10.1080/02671522.2013.787447

[70] Winston, K. A., Van Der Vleuten, C. P. M., \& Scherpbier, A. J. J. A. (2013). Remediation of at-risk medical students: theory 
in action. Bmc Medical Education, 13. doi: Artn 132 Doi 10.1186/1472-6920-13-132

[71] Yan, B., \& Kong, X. L. (2013). An Empirical Study on Effective Teaching of PE Teachers. 2013 3rd International Conference on Education and Education Management (Eem
2013), 27, 678-683.

[72] Youngs, P., \& King, M. B. (2002). Principal leadership for professional development to build school capacity. Educational Administration Quarterly, 38(5), 643-670. doi: Doi 10.1177/0013161x02239642 